\title{
Green Network Approach for Integrated Wireless Network Used in Rural India
}

\author{
Shashikant S. Hippargi, PhD \\ Research Student \\ Department of Electronics and Telecommunication \\ Engineering \\ SVERI's C.O.E., Pandharpur, Maharastra State, \\ India
}

\begin{abstract}
India being known as an agricultural country, power for the crop cultivation is one of the major concern in rural part of India. An efficient system to provide continuous power supply in rural area is still not available due to which production of proper crop is becoming difficult. Many Wireless Sensor Networks are designed for recording different parameters as temperature, humidity, soil moisture, fertilizer content in soil etc. All these Wireless Sensor Networks need continuous power to communicate all required parameters to researchers for giving proper solutions to farmers. Most of the power is generated by nuclear reactors, coal and renewable sources of energy. Most of the power requirement is furnished by thermal power plants which use coals as primary fuel but it increases the carbon percentage in environment. So, in this paper power generation by various renewable sources is discussed and a solar based electricity generation solution is proposed for integrated wireless networks. A solar based power supply is used as it is abundantly available to provide the energy required by sensor nodes in integrated wireless networks. A prediction algorithm is also implemented for prediction of suitable crop to be cultivated by gathering environmental information.
\end{abstract}

\section{Keywords}

ICT, Carbon content, PV, SOC.

\section{INTRODUCTION}

Agriculture and its allied services are the main occupations of India. Rural India suffers a lot of power cut due to which most of the time it becomes very much difficult to complete work to cultivate crops in time. In India $70 \%$ of the power cut which is more than 8 hours a day results in the use of 2 billion liters per year which results in 5 metric tons of $\mathrm{CO}_{2}$ [6]. To make available all the possible solutions to farmers Information and Communications Technology plays a vital role. Many solutions are proposed to connect these rural part of India with urban areas and integrated wireless network in one among them to provide last mile solutions. A continuous monitoring of parameters related to crop is needed which can be communicated over integrated wireless network to researchers. But to understand and analyze all these parameters, a continuous power supply is needed by wireless sensors network for uninterrupted communication. Due to interrupted power supply in these regions it is very much difficult to communicate parameters all the time whenever it is expected. So, a clean solution for power generation is needed which can provide the supply of continuous power to these networks. A solar based solution is implemented and discussed its advantages over conventional energy sources in this paper. A storage element is also used as solar energy is available only in day time.

\author{
Shrikant K. Bodhe, PhD \\ Research Guide \\ Department of Electronics and Telecommunication \\ Engineering \\ SVERI's C.O.E., Pandharpur, Maharastra State, \\ India
}

\section{RELATED WORK}

Huge research and work is in progress related to provide green solutions for power requirements all over the world.

A prediction is done in BRIC meeting that Indian power consumption will be doubled by 2020. Electricity consumption per capita will be around $84 \mathrm{KWh}$ in 2020 . There are around 500 million people in India without access to electricity and most of them are in rural India. Coal provides $70 \%$ of the total power generated by India [2].

India uses $1 \%$ of the total worldwide energy consumption which causes 130 million tons of emission of greenhouse gases and $\mathrm{CO}_{2}$. It is a result of due to extra infrastructure needed for ICT facility as data traffic is increasing almost 10 times in every 5 year [3]

By connecting people from rural part of India to all over the word a smart India can be envisioned. Green cloud computing, green wireless sensor networks, green machine to machine, green data centers and green radio frequency identification are needed to implement green ICT [4].

A report says that the emission of $\mathrm{CO} 2$ is almost the twice the absorption of it by natural process. ICT industries contribute to $2 \%$ of the global emission of $\mathrm{CO} 2$ among all the industries and also expenditure of $3 \%$ of global energy [5].

A possibility of Photo Voltaic (PV) and battery can be used to provide the energy to Green small cells. Correctly sized PV panel and battery can be used for efficient energy saving model [7].

A battery is generally represented as a buffer to store and exchange energy between source to load. Some of the work is done on very complex models and must be frequently updated depending upon the varying conditions. A non ideal battery is discussed on the parameters like State of Charge (SOC) [8], battery degradation [9] and energy leakage [10].

Using the soil parameters like $\mathrm{H}$, Nitrogen, moisture etc for crop yield prediction, Naive Bayes algorithm is used to classify the soil and a 77 percent accuracy is achieved. Apriori algorithm is used to associate the soil with the crops that could provide maximum yield in them. A comparison of accuracy achieved during classification using Nave Bayes, J48 and JRIP is also presented [12].

\section{IMPLEMENTATION}

To design an energy efficient model for integrated wireless networks as shown in Fig. 1 depends on three important parameters,

a. Low powered modules

b. Sleep-Awake model 
c. Solar based energy generation

\section{Fig 1: Block Diagram of Integrated Wireless Network}

As it is a wireless network, the communication of sensor parameter is made possible through integrating three networks, Bluetooth to Wi-Fi to GSM network for connecting rural India to any part of the world. So choice of low power modules for Module 1 (Sensor to Bluetooth), Module 2 (Bluetooth to $\mathrm{Wi}-\mathrm{Fi})$ and Module $3(\mathrm{Wi}-\mathrm{Fi}$ to GSM) is necessary. Low power controller is also chosen for processing and communication to reduce energy requirement.

\subsection{Selection of Low Powered Modules}

\section{Bluetooth Module:}

HC-05 is a low power Bluetooth module which requires $30 \mathrm{~mA}$ of current when active. It can be put into idle mode which requires only $3 \mathrm{~mA}$ of current. To make this module to work from active to idle and active whenever it is needed it can be put into SNIFF Mode. AT command can set SNIFF mode by,

$\mathrm{AT}+\mathrm{SNIFF}=\langle$ Param 1$\rangle,\langle$ Param2 $\rangle,\langle$ Param3 $\rangle,\langle$ Param4 $\rangle$

Param1: Max time

Param2: Min time

Param3: Retry time

Param4: Time out

SW <hexword>

For example 0x0020

It provides the $\mathrm{HC}-05$ to be in SNIFF mode for

$32 \times 0.625=20 \mathrm{~ms}$

A maximum of 20 seconds can be provided for SNIFF mode. It can be looped continuously to get HC-05 to be in SNIFF mode for longer durations. This can save a huge amount of energy as during awake mode this module requires 10 times more current as compared to idle mode. In this system two HC-05 are used so by using SNIFF mode energy is saved two times when compared to the system without SNIFF mode.

\section{Wi-Fi Module:}

ESP8266: It is a very low cost, low power and efficient Wi-Fi module. ESP8266 can be operated in four different modes to reduce energy required by it.

No Sleep mode: This mode keeps everything active all the time. So, it is the most inefficient way to work on energy module. In this system ESP8266 is never put on No sleep mode.

Modem Sleep mode: It is the default mode of ESP8266. In this mode modem (WiFi) is disabled and will be enabled only when it is connected to access point. The interval for the modem to be turned off will be decided by router. Following interface can be used to make ESP8266 in auto modem sleep mode.

\section{wifi_set_sleep_type(MODEM_SLEEP_T)}

Light Sleep mode: It works as same of Modem sleep mode, but here CPU will be suspended as it will be in idle condition and also system clock is turned off. Following interface can be used to set ESP8266 in auto light sleep mode,

wifi_set_sleep_type(LIGHT_SLEEP_T)

ESP8266 has to be woken up by an external GPIO. Interface required for waking up from light sleep mode is

void gpio_pin_wakeup_enable(uint32 i, GPIO_INT_TYPE intr_state);

Deep-Sleep Mode: If maximum power has to be saved then only Deep-sleep mode can be used. In this mode only RTC will work as it is responsible for waking up ESP8266 periodically. A very simple way to set ESP8266 in Deep Sleep mode using arduino IDE is

Const int sleeptimer 10;

ESP.deepSleep(sleeptimer * 1000000)

This command makes ESP8266 in deep sleep mode for 60 seconds To make deep sleep mode work GPIO16 is connected to EXT_RSTB. ESP8266 can be put in deep sleep mode for around 70 minutes. Current requirement in deep sleep mode is only $60 \mu \mathrm{A}$ when compared to $81 \mathrm{~mA}$ of current when it is in awake mode. Again, here in this system two ESP8266 in NodeMCU are used so, energy is saved two times when ESP8266 used in deep sleep mode when compared to regular awake mode. A very large amount of energy can be saved if, ESP8266 is used in awake and deep sleep mode. It is needed to be awaken only when parameter is expected by the user.

\subsection{Integration of PV / Battery for Green Energy}

In this paper a solution which is a combination of PV with Lead acid battery is provided. A solar panel to charge a $12 \mathrm{~V}$ battery is selected with around $1 \mathrm{Ah}$. In integrated wireless network most of the modules work on the voltages of 3.3v, $5 \mathrm{v}$ and GSM module works on voltages between $9 \mathrm{v}-12 \mathrm{v}$. Maximum current requirement is $500 \mathrm{~mA}$ by controllers so, a battery with $12 \mathrm{~V}$ with around $1 \mathrm{Ah}$ is chosen.

\section{$30.5 \mathrm{~cm} \mathrm{X} 25.5 \mathrm{~cm}$}

Specification of Solar Panel used

Rated power (Pm): 11W

Rated voltage (Vm): 17.2V

Rated current (Im): 0.63A 
Open circuit voltage (Voc): $21.6 \mathrm{~V}$

Short circuit current (ISC): 0.69A

Standard Test Condition (STC): $1000 \mathrm{~W} / \mathrm{m} 2 \mathrm{AM} 1.5$ at $25^{\circ} \mathrm{C}$

Output of solar panel is interfaced to battery with a circuit having parallel connection of capacitor $(1000 \mu \mathrm{F}, 25 \mathrm{~V})$, Voltage regulator (KA7812) and again a capacitor of $(470 \mu \mathrm{F}$, $25 \mathrm{~V}$ ) to provide a constant output of $12 \mathrm{~V}$ to battery.

Specification of Lead Acid Battery used:

12 Volt output with $1.3 \mathrm{Ah} / 20 \mathrm{HR}$

Cycle use: $14.4-15.0 \mathrm{~V}$

Standby use: 13.5 to $13.8 \mathrm{~V}$

Initial current: less than $0.39 \mathrm{~A}$.

Output of solar panel with interfaced circuit is used to charge lead acid battery to produce green energy for WSNs.

\subsection{Prediction Algorithm}

These sensors in the system when activated, collects the current the parameters like temperature, humidity etc of environment. The server consists of previous few years data. The current values collected through sensors are compared with already existing data in the server. Depending upon these values, the prediction algorithm analyses and predicts the suitable crops to be cultivated.

$\mathrm{T}_{\mathrm{n}}=$ Temperature

$\mathrm{H}_{\mathrm{n}}=$ Humidity

$\mathrm{M}_{\mathrm{n}}=$ Moisture

$\mathrm{U}_{\mathrm{n}}=$ Number of tests

For 1 to $n$

Test_avg $\left(T_{n}, H_{n}, M_{n}\right)$

$\mathrm{U}_{1}=\mathrm{T}_{1}+\mathrm{H}_{1}+\mathrm{M}_{1}$

$\mathrm{U}_{2}=\mathrm{T}_{2}+\mathrm{H}_{2}+\mathrm{M}_{2}$

$\mathrm{U}_{\mathrm{n}}=\mathrm{T}_{\mathrm{n}}+\mathrm{H}_{\mathrm{n}}+\mathrm{M}_{\mathrm{n}}$

End

$\mathrm{U}_{\text {avgt }}=\mathrm{U}_{\mathrm{t} 1}+\mathrm{U}_{\mathrm{t} 2}+\ldots+\mathrm{U}_{\mathrm{tn}} / \mathrm{U}_{\mathrm{tn} \text { (count) }}$

$\mathrm{U}_{\mathrm{avgh}}=\mathrm{U}_{\mathrm{h} 1}+\mathrm{U}_{\mathrm{h} 2}+\ldots+\mathrm{U}_{\mathrm{hn}} / \mathrm{U}_{\mathrm{hn}(\text { count })}$

$\mathrm{U}_{\mathrm{avgm}}=\mathrm{U}_{\mathrm{m} 1}+\mathrm{U}_{\mathrm{m} 2}+\ldots+\mathrm{U}_{\mathrm{mn}} / \mathrm{U}_{\mathrm{mn} \text { (count) }}$

$\operatorname{Std} \_m a t c h\left(U_{\text {avgt }}, U_{\text {avgh }}, U_{\text {avgm }}\right)$

//Comparison of Values Fetched to Standard Data

$\mathrm{S}_{\mathrm{t}}=\mathrm{C}_{\mathrm{tmin}}<=\mathrm{U}_{\mathrm{avgt}} \& \& \mathrm{C}_{\mathrm{tmax}}>=\mathrm{U}_{\mathrm{avgt}}$

$\mathrm{S}_{\mathrm{h}}=\mathrm{C}_{\mathrm{hmin}}<=\mathrm{U}_{\mathrm{avgh}} \& \& \mathrm{C}_{\mathrm{hmax}}>=\mathrm{U}_{\mathrm{avgh}}$

$\mathrm{S}_{\mathrm{m}}=\mathrm{C}_{\mathrm{mmin}}<=\mathrm{U}_{\mathrm{avgm}} \& \& \mathrm{C}_{\mathrm{mmax}}>=\mathrm{U}_{\mathrm{avgm}}$

$\operatorname{Sugcrop}\left(\mathrm{S}_{\mathrm{t}}, \mathrm{S}_{\mathrm{h}}, \mathrm{S}_{\mathrm{m}}\right) / /$ According to values the relative crops are displayed

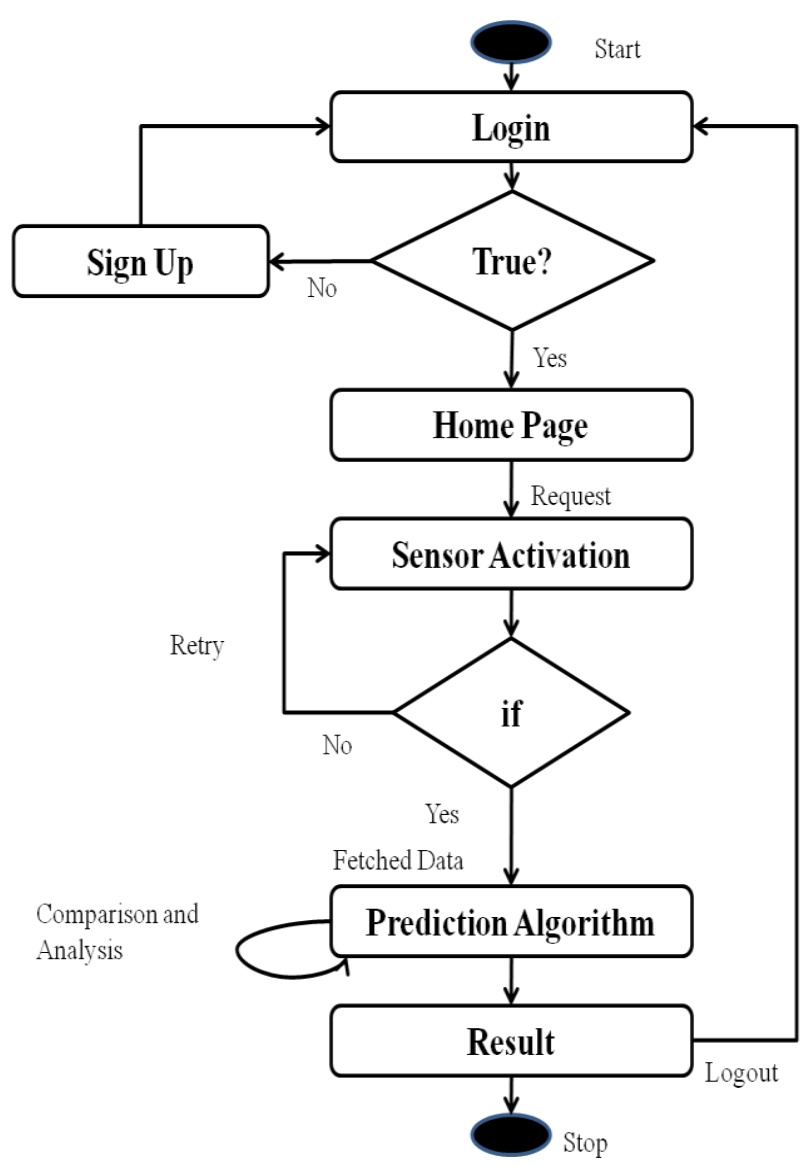

Fig 2: Flow chart for prediction of crops to be cultivated

\section{BATTERY CHARGING FROM SOLAR PANEL}

For calculations of charging of battery from PV it is assumed that effective capacity is $50 \%$ of stated capacity i.e. at least $50 \%$ of the battery is charged initially or battery must never be discharged less than $50 \%$. It is also assumed that battery capacity is the true capacity.

Solar panel is of $11 \mathrm{~W}, 17.2 \mathrm{Volt}$

Battery to be charged is Lead acid battery with $12 \mathrm{~V}, 1.3 \mathrm{Ah}$ ratings.

So, Time to charge from $50 \%$ full to $100 \%$ full is

Time $=$ Battery capacity $(\mathrm{Wh}) /$ Panel power $(\mathrm{W}) * 2$

i.e.

Panel power in $\mathrm{W}=11 \mathrm{~W}$

Battery Capacity in $\mathrm{Wh}=12 \mathrm{~V} * 1.3 \mathrm{Amp}$ hour

$$
=15.6 \mathrm{Wh}
$$

So, Time $=(15.6 / 11) * 2$

$$
=2.83 \mathrm{hrs}
$$

Approximately 2 hrs 50 minutes

Solar panel has also effect of temperature on power output. Approximately a decrease in output power is $0.5 \% / 25^{\circ} \mathrm{C}$

It is taken care while taking the readings to maintain proper angle of solar panel to sun which is approximately $90^{\circ}$ because angle to sun also effect in \% of power output [11]as shown in Table 1. 
Table 1: Percentage of output power with angle of solar panel to sun

\begin{tabular}{|l|l|}
\hline Angle to Sun & \% Output \\
\hline 90 & 100 \\
\hline 75 & 97 \\
\hline 60 & 88 \\
\hline 45 & 77 \\
\hline 30 & 61 \\
\hline 15 & 32 \\
\hline
\end{tabular}

\section{RESULTS}

Table 2 shows the practical values taken to charge the lead acid battery from solar panel. Battery was initially charged to $8.15 \mathrm{~V}$ to ensure that battery should not be dead. It can be observed that initially battery charges at faster rate than later.

Table 2: Open circuit Battery voltages

\begin{tabular}{|l|l|l|l|l|l|}
\hline $\begin{array}{l}\text { Sr. } \\
\text { No. }\end{array}$ & Time & $\begin{array}{l}\text { Output } \\
\text { Voltage } \\
\text { from } \\
\text { Solar } \\
\text { Panel } \\
\text { (Volts) }\end{array}$ & $\begin{array}{l}\text { Input } \\
\text { Voltage } \\
\text { to } \\
\text { Battery } \\
(\text { Volts })\end{array}$ & $\begin{array}{l}\text { Open } \\
\text { Circuit } \\
\text { Battery } \\
\text { Voltage } \\
\text { (Volts) }\end{array}$ & $\begin{array}{l}\text { Temp. } \\
\left({ }^{\circ} \mathbf{C}\right)\end{array}$ \\
\hline 1 & $7.20 \mathrm{am}$ & 19.02 & 12.18 & 8.15 & 26 \\
\hline 2 & $7.50 \mathrm{am}$ & 18.80 & 12.17 & 11.25 & 26 \\
\hline 3 & $8.05 \mathrm{am}$ & 19.01 & 12.18 & 11.37 & 27 \\
\hline 4 & $8.15 \mathrm{am}$ & 19.44 & 12.18 & 11.44 & 27 \\
\hline 5 & $8.30 \mathrm{am}$ & 18.87 & 12.17 & 11.48 & 28 \\
\hline 6 & $8.50 \mathrm{am}$ & 19.02 & 12.18 & 11.55 & 29 \\
\hline 7 & $9.30 \mathrm{am}$ & 19.02 & 12.18 & 11.66 & 31 \\
\hline 8 & $\begin{array}{l}11.30 \\
\mathrm{am}\end{array}$ & 19.01 & 12.18 & 11.82 & 32 \\
\hline 9 & $\begin{array}{l}12.15 \\
\mathrm{am}\end{array}$ & 18.86 & 12.17 & 11.98 & 34 \\
\hline
\end{tabular}

Highlighted sample of the readings taken while charging the lead acid battery from solar panel are shown in following figures.

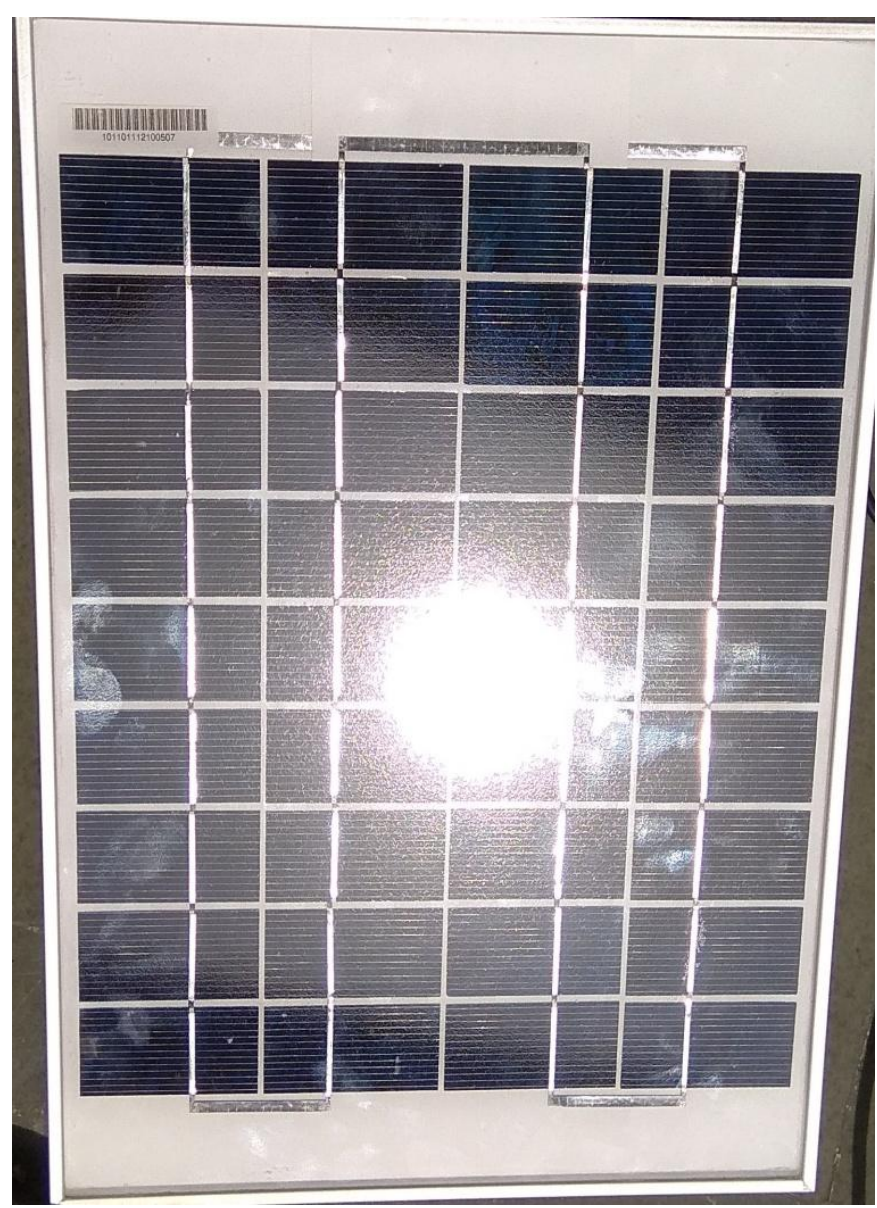

Fig 3: 11W 17V Solar Panel at $90^{\circ}$ to sun

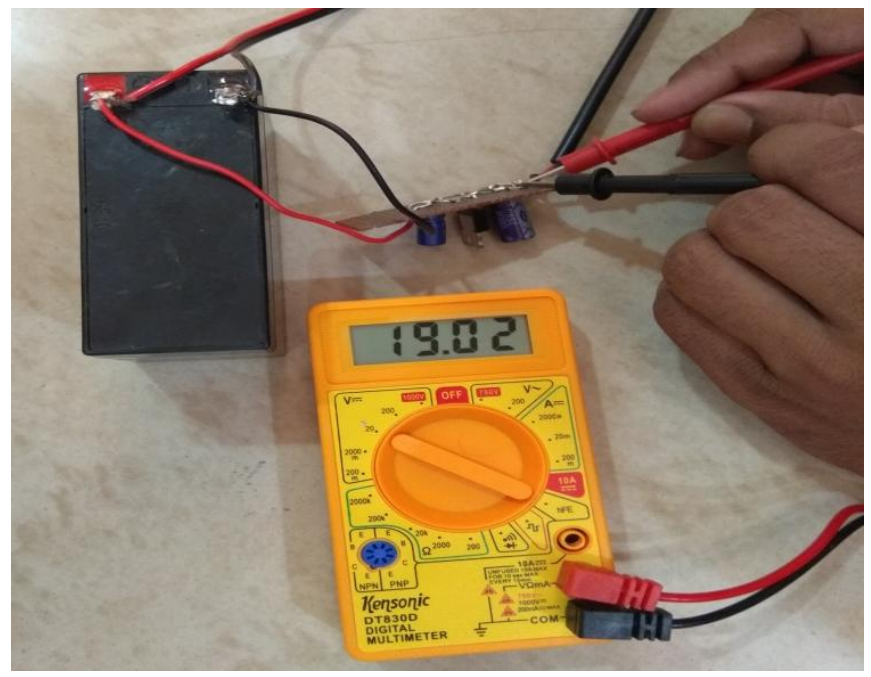

Fig 4: Output Voltage from Solar Panel (Volts) 


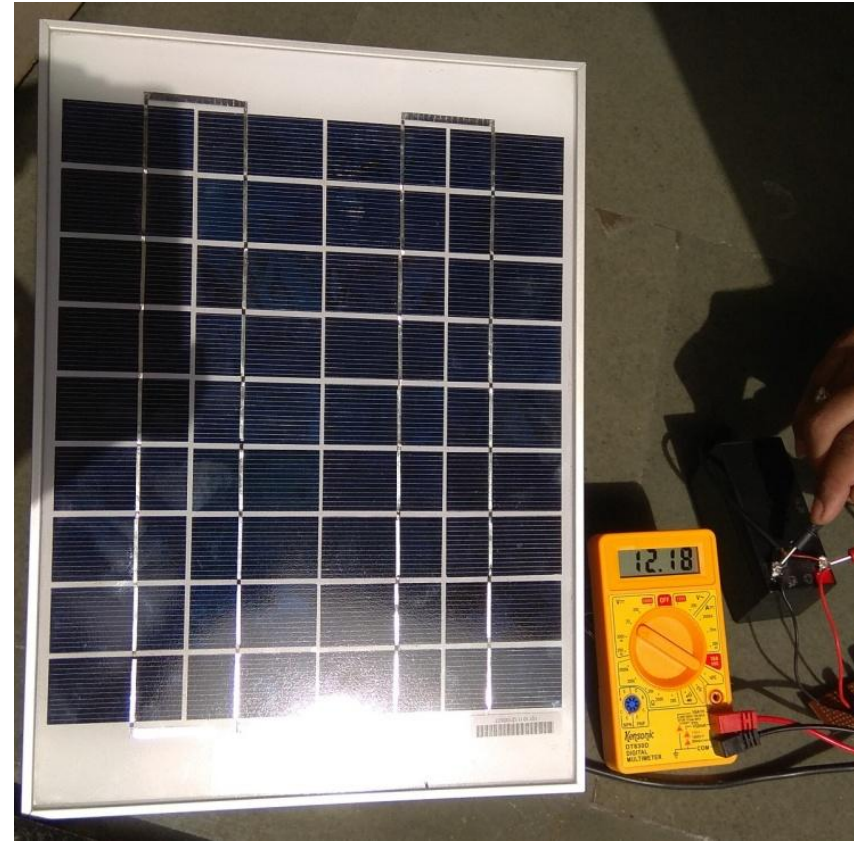

Fig 5: Input Voltage to Battery (Volts)

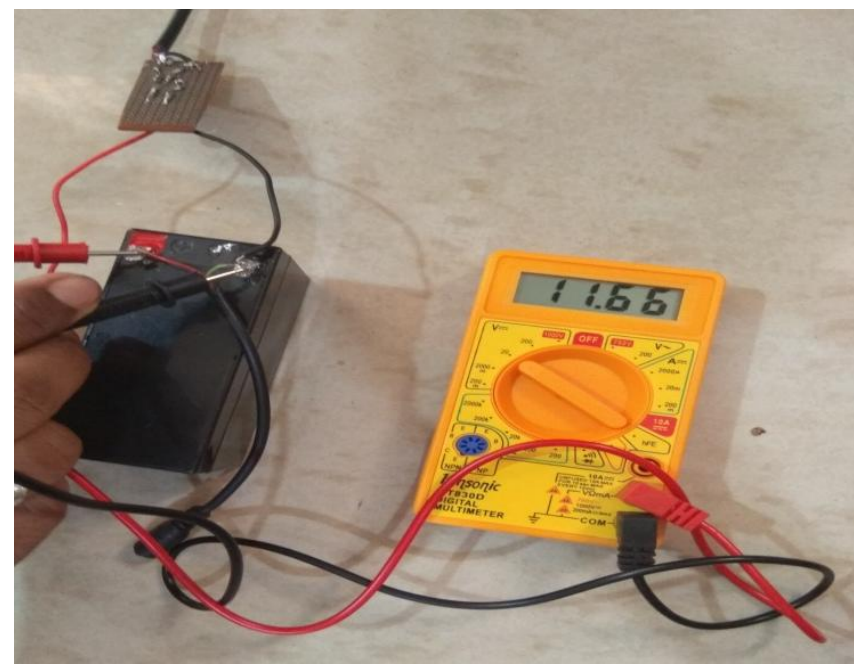

Fig 6: Open Circuit Battery Voltage (Volts)

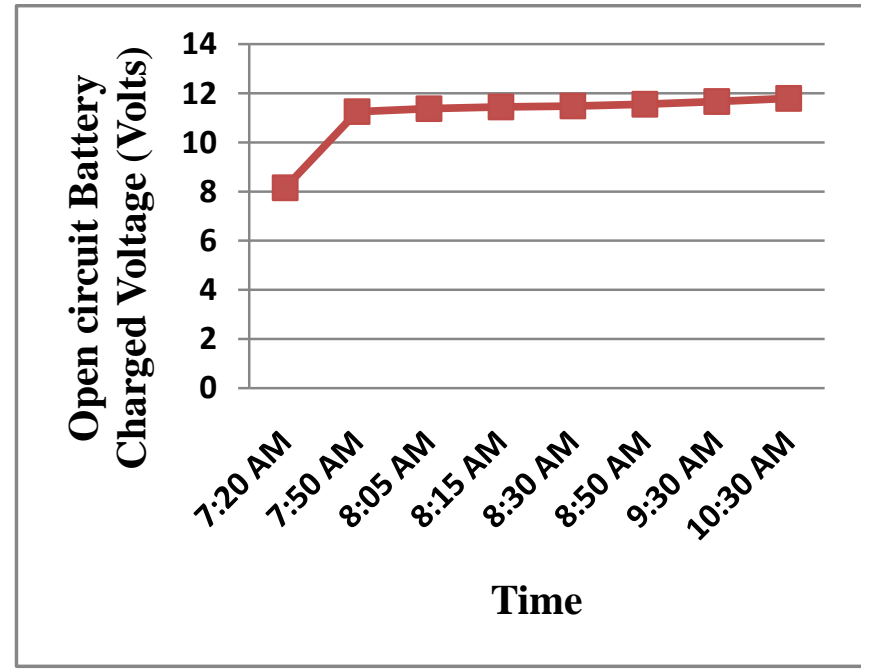

Fig 7: Plot of time versus open circuit voltage of battery
Once battery is charged and connected to our wireless integrated circuits then all our supply is generated from PV hence reducing in carbon level in environment. This panel can be always connected to battery for continuous supply and by making the whole system to work on sleep-awake mode energy can be saved many a fold.

Figure 8 shows the predicted crop depending on environmental conditions sensed by the sensors from module 1.

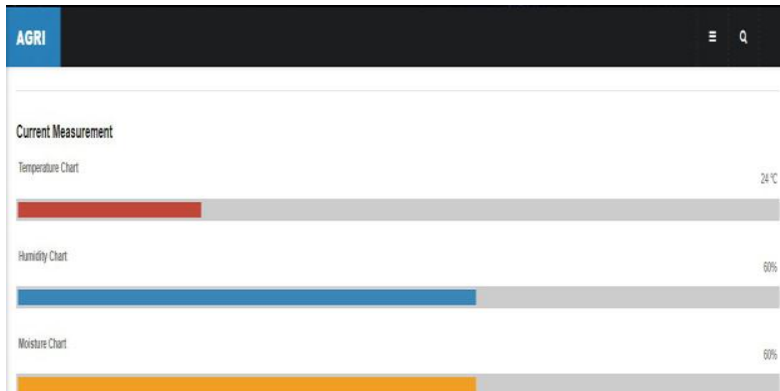

Sugpested Crops

Wheat

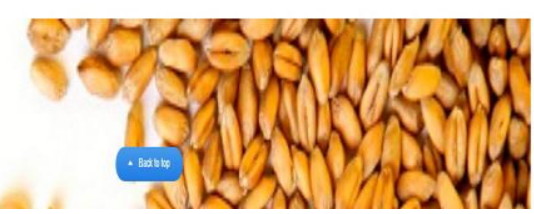

Fig 8: Predicted crops depending on environmental conditions

\section{CONCLUSION}

In this paper, a prototype for Green communication is implemented using solar energy as one of the green sources. System is made to consume less power by making the whole system to work in sleep-awake mode. An uninterrupted supply can be provided by the use of Green sources. A large amount of energy can be saved with this model. If implemented on a large scale for all WSNs then carbon level in environment can be reduced due to infrastructure needed for communication. Further a system can be designed to rotate solar panel with sun to increase the efficiency of the whole system which was done manually in this prototype. A green network can be implemented by using this prototype and rural part of India can be connected with less power requirement to rest of the world. The prediction algorithm is implemented which takes current parameters of environment such as temperature and humidity values from the sensors as input and performs analysis with historical data then predicts which crop is suitable for cultivation. Further this algorithm can be extended with other parameters like $\mathrm{Ph}$ value of soil.

\section{REFERENCES}

[1] https://www.indiainfoline.com/article/news-sectorothers/india-power-consumption-to-double-by-2020kpmg-ic-report-113100701456_1.html.

[2] Md Munjure Mowla and Daryoush Habibi, "A Green Communication Model for 5G Systems", IEEE Transactions on Green Communications and Networking, DOI 10.1109/TGCN.2017.2700855.

[3] G. Fettweis and E. Zimmermann, "ICT energy consumption-trends and challenges", in Proc. IEEE Int. 
Symp. Wireless Personal Multimedia Commun., Lapland, Finland, Sept. 2008, pp. 1-6.

[4] CHUNSHENG ZHU, VICTOR C. M. LEUNG, LEI SHU and EDITH C.-H. NGAI, "Green Internet of Things for Smart World”, IEEE Access, VOLUME 3, Nov. 2015.

[5] Kelly T, a report on "ICTs and climate change. ITU-T Technology", 2007.

[6] A. Jhunjhunwala et. al., "Powering Cellular Base Stations: A Quantitative Analysis of Energy Options", Technical Report, Indian Institute of Technology, Madras, 2012.

[7] Mouhcine Mendil, Antonio De Domenico, Vincent Heiries, Raphael Caire, and Nouredine Hadjsaid, "Battery-Aware Optimization of Green Small Cells:Sizing and Energy Management", IEEE Transactions on Green Communications and Networking, 2018.

[8] A. Biason and M. Zorzi, "On the effects of battery imperfections in an energy harvesting device", in
Computing, Networking and Communications (ICNC), 2016 International Conference on. IEEE, 2016, pp. 1-7

[9] L. Badia, E. Feltre, and E. Gindullina, "A markov model accounting for charge recovery in energy harvesting devices," in Wireless Communications and Networking Conference Workshops (WCNCW), 2017 IEEE. IEEE, 2017, pp. 1-6.

[10] N. Michelusi, et al., "Energy management policies for harvesting-based wireless sensor devices with battery degradation," IEEE Transactions on Communications, vol. 61, no. 12, pp. 4934-4947, 2013.

[11] https://www.voltaicsystems.com/blog/estimating-batterycharge-time-from-solar/

[12] Hemageetha, N., "A survey on application of data mining techniques to analyze the soil for agricultural purpose", Computing for Sustainable Global Development (INDIACom), 16426375, March 2016, New Delhi, India. 